\title{
Olanzapine-associated hypothermia in an adolescent anorexic girl
}

\author{
Martine K. F. Docx ${ }^{1 *}$, Annik Simons ${ }^{2}$, José Ramet ${ }^{3}$, Luc Mertens ${ }^{4}$, Paul Govaert ${ }^{1}$ \\ ${ }^{1}$ Department of Paediatrics, Queen Paola Children’s Hospital, Antwerp, Belgium \\ ${ }^{2}$ Department of Child Psychiatry, Queen Paola Children's Hospital, Belgium and University of Antwerp, Antwerp, Belgium \\ ${ }^{3}$ Department of Paediatrics, University Hospital, Antwerp, Belgium \\ ${ }^{4}$ Division of Cardiology, The Hospital for Sick Children, Toronto, Canada \\ Email: martine.docx@zna.be, annik.simons@zna.be, jose.ramet@uza.be, luc.mertens@sickkids.ca, paul.govaert@zna.be
}

Received 28 June 2012; revised 27 July 2012; accepted 17 August 2012

\begin{abstract}
This is a 12th case report on olanzapine induced hypothermia and based on the results of literature search, by far is the youngest case ever is reported. The hypothermia occurred during the refeeding phase, despite a weight gain since increasing the dosage from $5 \mathrm{mg}$ to $7.5 \mathrm{mg}$ olanzapine. Our recent literature search found 11 published cases of olanzapine treatment associated with hypothermia. Olanzapine acts on serotonin or dopamin receptors and has antagonistic properties on histaminergic, muscarinic and $\alpha$-adrenergic receptors. Olanzapine mediates the hypothermic effect through antagonism at receptors other than dopamine.
\end{abstract}

Keywords: Anorexia Nervosa; Olanzapine; Hypothermia

\section{BACKGROUND}

The traditional definition of hypothermia is a drop in core temperature below $35^{\circ} \mathrm{C}$. The hypothalamus, more precisely the hypothalamic pre-optic region, is assumed to work as a coordinating center with involvement of dopamine, serotonin, norepinephrin and $\alpha$-adrenergic receptors [1-3]. Cerebrovascular autoregulation of our core temperature remains intact until below $25^{\circ} \mathrm{C}$; the latter helps maintain the cortical blood flow [4]. The most common causes of hypothermia are due to environmental exposure to low ambient temperatures. Other causes are septicemia, diabetic ketoacidosis, malnutrition, multisystem trauma, acute spinal cord injury, prolonged cardial arrest and hypothyroidism. Major side effects of olanzapine and other second-generation antipsychotics, like risperdone, quetiapine, aripipazole, paliperidone and ziprasidone are temperature dysregulation (mostly hyper-

\footnotetext{
"Corresponding author.
}

thermia, less often hypothermia) and the neuroleptic malignant syndrome, a life threatening event. Other side effects seen by neuroleptic drugs are include sedation, weight gain, hyperglycemia, orthostatic hypotension, dizziness, constipation, urinary retention, discoloration of teeth and dental problems and occasionally seizures [3,5-9]. Drug may increase triglyceride, cholesterol and transaminase levels [10]. Olanzapine (Zyprexa ${ }^{\circledR}$ ), an atypical antipsychotic drug, is considered for the management of psychosis, and is also used off-label for treating anorexic adolescents [11]. In a recent paper were olanzapine was used for the adjunctive treatment of adolescents with anorexia nervosa; the patients treated with olanzapine have a greater illness severity, acuity and comorbidity than the control population. Despite the inherent differences between both groups, the authors were unable to draw any firm conclusions regarding the potential efficacy of olanzapine and the rate of weight gain was not statistically different between both groups [10].

The mechanism of olanzapine-induced temperature dysregulation may include antagonism of the dopamine D2 and 5-hydroxytryptamine 2 (5HT2) receptors [9].

\section{CASE REPORT}

L. was a 14-year-old girl with a restrictive type of anorexia nervosa since the age of 13 years [BMI: $14.0 \mathrm{~kg} / \mathrm{m}^{2}$ ] when she was admitted to our tertiary eating disorder unit. Her personal history was complicated at the age of 12 years by an ablation for Wolff-Parkinson-White syndrome. Her family history was noticeable for her paternal grandmother with bipolar disorder and her father with depression. She presented with hypothermia $\left(34.5^{\circ} \mathrm{C}\right.$ oral temperature electronic thermometer day 141 of her second admission) during refeeding, despite appreciable weight gain [BMI: $16.7 \mathrm{~kg} / \mathrm{m}^{2}$ day 0 at second admission to BMI: $18.1 \mathrm{~kg} / \mathrm{m}^{2}$ day 141]. On the first admission in the acute state 1 year ago and during the second admission several measurements of her body temperature had 
been above $35.0^{\circ} \mathrm{C}$, until she started complaining of syncope, subjective coldness with shivering and acrocyanosis on day 141 when olanzapine was gradually increased to $7.5 \mathrm{mg} /$ daily olanzapine [(Zyprexa $\left.{ }^{\circledR}\right)$ first $2.5 \mathrm{mg}$ daily day 71 gradually increased $5 \mathrm{mg}$ /daily day 78 and $7.5 \mathrm{mg}$ daily since day 141]. First risperdone (Risperdal ${ }^{\circledR}$ ) $0.50 \mathrm{mg} /$ daily was first started from day 1 to day 71 (Risperdal ${ }^{\circledR}$ ) for borderline-psychotic behaviour namely, body image delusions and irritability and switched to olanzapine on day 71 because of insufficient effect on moodstabilizing. She was also on sertraline (Serlain ${ }^{\circledR}$ ) $150 \mathrm{mg}$ daily since the first day of her hospitalisation for a depressive behaveiour. During the time she took risperdone, her oral temperature was between $35.9^{\circ} \mathrm{C}-36.3^{\circ} \mathrm{C}$.

Her physical exam was significant for an oral temperature of $34.5^{\circ} \mathrm{C}$ taken in sitting position measuring with an electronic thermometer, blood pressure of 86/59 mm $\mathrm{Hg}$, pulse rate of $42 \mathrm{bpm}$ and an oxygen saturation of $98 \%$ in room air. Weight: $47.5 \mathrm{~kg}$; Height: $162 \mathrm{~cm}$ and BMI was $18.1 \mathrm{~kg} / \mathrm{m}^{2}$. Her heart sounds were regular and bilateral lung auscultation was clear. The extremities demonstrated mild acrocyanosis without pitting edema. Neurologic examination revealed a slurred speech and normal tendon reflexes of all extremities.

Laboratory data included the following values: a white blood cell count (WBC) of $5.9 \times 10^{3} / \mathrm{cm}^{3}$, a haemoglobin concentration of $14.3 \mathrm{~g} / \mathrm{dL}$, a hematocrit of $0.420 \mathrm{~L} / \mathrm{L}$, a platelet count of $200 \times 10^{3} / \mathrm{cm}^{3}$; serum sodium $144 \mathrm{mEq} / \mathrm{L}$; potassium $4.0 \mathrm{mEq} / \mathrm{L}$; chloride $106 \mathrm{mEq} / \mathrm{L}$; BUN 35 $\mathrm{mg} / \mathrm{dL}$; creatinine $0.78 \mathrm{mg} / \mathrm{dL}$; glucose $78 \mathrm{mg} / \mathrm{dL}$. Liver enzymes and albumin were normal. Thyroid function tests were within the normal range. Cholesterol and triglycerides levels were also normal.

QT- and QTc intervals measured in lead II were normal during the hypothermic period and also during the further hospitalisation. A sinus bradycardia of $49 \mathrm{bpm}$ without rhytm disturbances was registered on the ECG on day 141. After cessation of olanzapine the heart rate increased till 59 bpm on day 151 and till 66 bpm on day 155 when olanzapine was reintroduced (see Figure 1).

Her temperature gradually rose spontaneously after withdrawal of olanzapine in 13 days and then continued to rise to normal following reintroduction of olanzapine at a lower dosage [2.5 mg/daily started on day 155 and 5 mg/daily started on day 164] (see Figure 1).

\section{LITERATURE REVIEW}

This is the twelfth reported patient with olanzapine-induced hypothermia and the youngest pediatric patient with olanzapine-induced hypothermia described in the literature (PubMed Search for olanzapine and hypothermia 13.09.2011) (see Table 1) [5-9,12-16]. According to the literature, the risk of hypothermia is highest following initiation of the drug or after an increase in dosage. The most frequent diagnosis involved in these situations is schizophrenia [5].

\section{DISCUSSION}

In the case of the anorexic girl described here, hypothermia started during the refeeding phase, when olanzapine was initiated at a rapidly increasing dosage. Hypother-

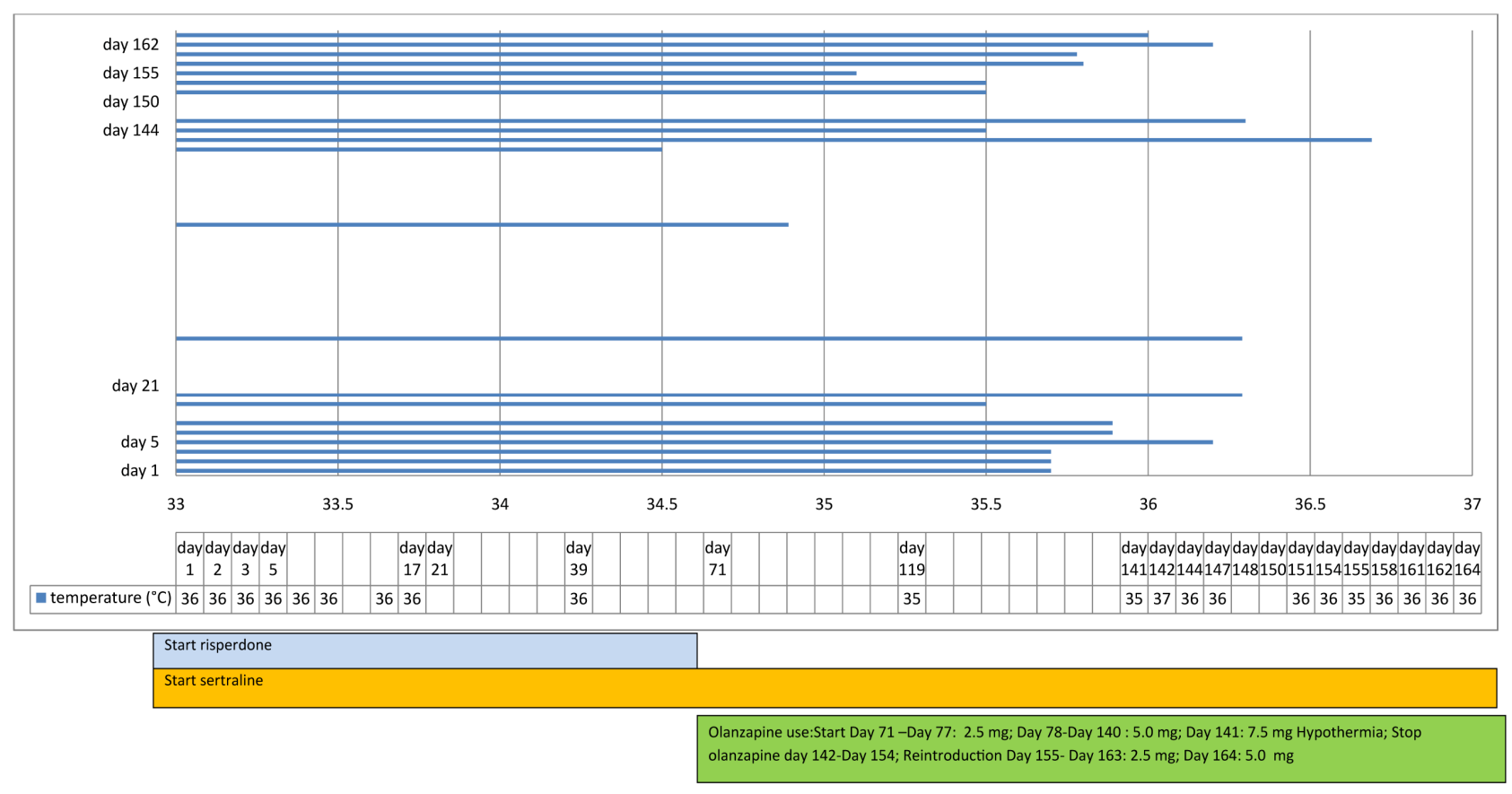

Figure 1. Olanzapine. 
Table 1. Summary of cases published in PUBMED-Search: Hypothermia and olanzapine.

\begin{tabular}{|c|c|c|c|c|c|c|c|}
\hline Author & & $\begin{array}{l}\text { Age } \\
(y)\end{array}$ & Gender & Indication & $\begin{array}{c}\text { Disease \& } \\
\text { Hypothermia }\end{array}$ & $\begin{array}{l}\text { Dosage Olanzapine } \\
\text { \& Comedication }\end{array}$ & Treatment \\
\hline 1. Phan TG. et al. & 1998 & 37 & $\mathrm{~F}$ & Psychotic Disorder & $\begin{array}{l}\text { Prader-Willi Syndrome } \\
\text { Hypothermia }\end{array}$ & $\begin{array}{l}\text { Single dose olanzapine } \\
\text { \& Risperdone }\end{array}$ & $\begin{array}{l}\text { Cessation Olanzapine } \\
\text { Start Levothyroxine }\end{array}$ \\
\hline 2. Hägg S. et al. & 2001 & 73 & $\mathrm{~F}$ & Schizophrenia & $\begin{array}{l}\text { Somnolence } \\
\text { Hypotension } \\
\text { Prolonged QT-interval } \\
\text { AV block type-1 } \\
\text { Repeated episodes of } \\
\text { hypothermia } 31.5^{\circ} \mathrm{C}\end{array}$ & $\begin{array}{l}4 \text { hrs of the single dose } \\
\text { olanzapine } 10 \mathrm{mg} \mathrm{\&} \\
\text { Perphenazine }\end{array}$ & $\begin{array}{l}\text { Cessation Antipsychotic } \\
\text { Treatment } \\
\text { Warmed intravenous fluids } \\
\text { Heating lamp } \\
\text { Warmed blankets }\end{array}$ \\
\hline 3. Parris C. et al. & 2001 & 83 & $\mathrm{~F}$ & Bipolar Disorder & $\begin{array}{l}\text { Dementia } \\
\text { Catatonia } \\
\text { Hypertension } \\
\text { Hypothermia } 33.1^{\circ} \mathrm{C} \\
\text { Lethargy }\end{array}$ & $\begin{array}{l}\text { After } 3 \text { weeks } 5 \text { mg/d } \\
\text { olanzapine \& Lithium } \\
\text { carbonate, Piroxicam, } \\
\text { Clonazepam and } \\
\text { Trazodone hydrochloride }\end{array}$ & $\begin{array}{l}\text { Cessation all medication } \\
\text { Warmed blankets } \\
\text { Warmed intravenous } \\
\text { fluids }\end{array}$ \\
\hline 4. Fukunishi I. et al. & 2003 & 54 & M & Night Delirium & $\begin{array}{l}\text { Visual hallucinations } \\
\text { ESRD-hemodialysis } \\
\text { Hypothermia } 34.0^{\circ} \mathrm{C}\end{array}$ & $\begin{array}{l}\text { Olanzapine } 2.5 \mathrm{mg} / \mathrm{d} \text { for } \\
10 \text { days }\end{array}$ & $\begin{array}{l}\text { Cessation olanzapine } \\
\text { Pharmacokinetic } \\
\text { Interactions in ESRD } \\
\text { patient }\end{array}$ \\
\hline 5. Lee TW. et al. & 2003 & 84 & M & $\begin{array}{l}\text { Mixed Dementia } \\
\text { (Alzheimer + } \\
\text { Vascular) }\end{array}$ & $\begin{array}{l}\text { Long-term hypertension } \\
\text { Bradycardia ( } 40 \mathrm{bpm}) \\
\text { Hypotension }(50 / 30 \mathrm{~mm} \\
\text { Hg) Hypothermia } 35.6^{\circ} \mathrm{C}\end{array}$ & $\begin{array}{l}\text { Olanzapine } 2.5 \text { mg \& } \\
\text { Aspirin, Captopril, } \\
\text { Zolpiclone }\end{array}$ & $\begin{array}{l}\text { Cessation all medication } \\
\text { Extra intravascular fluid }\end{array}$ \\
\hline 6. Blass DM. et al. & 2004 & 64 & $\mathrm{~F}$ & Bipolar Disorder & $\begin{array}{l}\text { Type II Diabetes Mellitus } \\
\text { Hypothyroidism } \\
\text { Hypothermia } 33.4^{\circ} \mathrm{C}\end{array}$ & $\begin{array}{l}\text { Gradually titrated } \\
\text { olanzapine } 2.5 \text { to } \\
6.25 \text { mg \& Gabapentin }\end{array}$ & $\begin{array}{l}\text { Cessation Olanzapine } \\
\text { Start Levothyroxine }\end{array}$ \\
\hline 7. Hung CF. et al. & 2009 & 17 & M & $\begin{array}{l}\text { Schizophreniform } \\
\text { Disorder }\end{array}$ & $\begin{array}{l}\text { Rhabdomyolysis CK } \\
\text { (5525 U/L) Hypotension } \\
\text { (90/50 mm Hg) } \\
\text { Bradycardia (54 bpm) } \\
\text { Hypothermia }\end{array}$ & $\begin{array}{l}\text { After intramuscular } \\
\text { injection once } 5 \mathrm{mg} \\
\text { olanzapine }\end{array}$ & $\begin{array}{l}\text { Alkalized fluid infusion } \\
\text { Forced diuresis } \\
\text { Warmed blankets }\end{array}$ \\
\hline $\begin{array}{l}\text { 8. Rasnayake LR. } \\
\text { et al. }\end{array}$ & 2011 & 42 & M & $\begin{array}{l}\text { Paranoid } \\
\text { Schizophrenia }\end{array}$ & $\begin{array}{l}\text { Somnolence } \\
\text { Reduced muscle tone } \\
\text { Bradycardia ( } 48 \mathrm{bpm}) \\
\text { with J waves } \\
\text { Hypotension } \\
(90 / 60 \mathrm{mmHg}) \\
\text { Hypothermia } 32.0^{\circ} \mathrm{C}\end{array}$ & $\begin{array}{l}\text { Since } 6 \text { years olanzapine } \\
10 \mathrm{mg} / \mathrm{d}\end{array}$ & $\begin{array}{l}\text { Cessation Olanzapine } \\
\text { Rewarming gradually } \\
\text { Warm saline infusion }\end{array}$ \\
\hline 9. Kreuzer P. et al. & 2011 & 51 & $\mathrm{~F}$ & $\begin{array}{l}\text { Catatonic } \\
\text { Schizophrenia }\end{array}$ & $\begin{array}{l}\text { BMI: } 15 \mathrm{~kg} / \mathrm{m}^{2} \\
\text { Hypothyroidism } \\
\text { Hypothermia } 30.0^{\circ} \mathrm{C}\end{array}$ & $\begin{array}{l}16 \text { days after increasing } \\
\text { dose from } 20 \text { mg to } \\
30 \mathrm{mg} / \mathrm{d} \text { olanzapine } \& \\
\text { Lorazepam , Thyroxine }\end{array}$ & $\begin{array}{l}\text { Cessation Olanzapine } \\
\text { Cardiopulmonary } \\
\text { Monitoring } \\
\text { Warmed blankets } \\
\text { Endocrine work-up }\end{array}$ \\
\hline 10. Kreuzer P. et al. & 2011 & 48 & $\mathrm{~F}$ & $\begin{array}{l}\text { Catatonic } \\
\text { Schizophrenia }\end{array}$ & $\begin{array}{l}\text { Hypoxia ( } 80 \%) \\
\text { Somnolent-Confused } \\
\text { Light-rigid pupils } \\
\text { Leukopenia }(2900 / \mu \mathrm{L}) \\
\text { Hypothermia } 31.0^{\circ} \mathrm{C}\end{array}$ & Once olanzapine 5 mg & $\begin{array}{l}\text { Cessation Olanzapine } \\
\text { Rewarmed } \\
\text { Cardiopulmonary } \\
\text { monitoring }\end{array}$ \\
\hline 11. Kreuzer P. et al. & 2011 & 69 & M & $\begin{array}{l}\text { Acute } \\
\text { Schizophrenic } \\
\text { Disorder }\end{array}$ & $\begin{array}{l}\text { Optic hallucinations } \\
\text { Paranoia AV block type- } 3 \\
\text { Hypothermia } 33.0^{\circ} \mathrm{C}\end{array}$ & $\begin{array}{l}\text { After single dose } \\
\text { olanzapine } 10 \mathrm{mg} / \mathrm{d} \& \\
\text { Lorazepam } 3 \text { to } 4.5 \mathrm{mg} / \mathrm{d}\end{array}$ & $\begin{array}{l}\text { Cessation Olanzapine } \\
\text { Rewarmed }\end{array}$ \\
\hline
\end{tabular}


mia-unrelated to drug use has already been reported in anorexic patients with a BMI $<13 \mathrm{~kg} / \mathrm{m}^{2}$ and latent transient primary hypothyroidism or low T3 syndrome before refeeding [17]. In contrast, onset of hypothermia developed abruptly in our patient during the refeeding phase, when the BMI had already increased to $18.1 \mathrm{~kg} / \mathrm{m}^{2}$ and the thyroid function tests were normal. Also risperdone used in the first weeks for borderline-psychosis can also cause hypothermia, but her oral temperature observed during that treatment was not in the hypothermic range. This is an argument in favour of olanzapine as the primary cause of her hypothermia.

Since the introduction of the drug in 1996 for clinical use, the database of the Adverse Drug Reactions linked in 2006 hypothermia to olanzapine use.The underlying mechanisms are still unclear. In 2000 Oerther and Ahlenus made the suggestion that olanzapine-induced hypothermia may be explained by a direct inhibitory effect on the sympathetic outflow and brown adipose tissue thermogenesis [18].

Metabolism of olanzapine is via CYP $1 \mathrm{~A} 2$ pathways, with no relevant genetic polymorphisms currently on record $[7,8]$. It is known that in normal humans there is a balance between the down-regulation of the body temperature by dopamine and the up-regulation of the body temperature by serotonin. Hypothermia induced by olanzapine could be mediated through antagonism of mostly D2 receptors but also due to antagonism of the $5-\mathrm{HT}_{2}$ receptors, for which we now know that olanzapine has a high affinity [9].

We suspect that hypotension and bradycardia in our patient were provoked by olanzapine use, namely by blockage of the $\alpha_{2}$-adrenergic receptors [15]. The latter might also increase the hypothermic effect by inhibiting peripheral responses to cooling of the body [9].

\section{SUMMARY AND CONCLUSION}

Medication-induced hypothermia can go unnoticed in patients, and in extreme cases can be life-threatening. The symptoms and signs are delirium, slurred speech, ataxia, shivering, subjective coldness, fatigue, incoordination and bradycardia. These can be mistaken for symptoms seen in an acute state of undernutrition in anorexic patients. Therefore, when antipsychotic drugs are prescribed or increased in dosage, clinicians should be aware of drug-induced hypothermia. In such a context, it is necessary to monitor body temperature very carefully, registering in detail the temperature and vital signs along with the correct dosage of the drug and the time interval of increase in dose.

\section{REFERENCES}

[1] Bymaster, F.P., Hemrick-Luecke, S.K., Perry, K.W. and
Fuller, R.W. (1996) Neurochemical evidence for antagonism by olanzapine of dopamine, serotonin, $\alpha_{1}$-adrenergic and muscarinic, receptors in vivo in rats. Psychopharmacology, 124, 87-94. doi:10.1007/BF02245608

[2] Bymaster, F.P., Nelson, D.L., DeLapp, N.W., Falcone, J.F., Eckols, K., Truex, L.L., Foreman, M.M., Lucaites, V.L. and Calligaro, D.O. (1999) Antagonism by olanzapine of dopamine D1, serotonin2, muscarinic, histamine $\mathrm{H}_{1}$ and $\alpha_{1}$-adrenergic receptors in vitro. Schizophrenia Research, 37, 107-122. doi:10.1016/S0920-9964(98)00146-7

[3] Razaq, M. and Samma, M. (2004) A case of risperdoneinduced hypothermia. American Journal of Therapeutics, 11, 229-230. doi:10.1097/00045391-200405000-00012

[4] Danzl, D. (2002) Hypothermia. Seminars in Respiratory and Critical Care Medicine, 23, 57-68. doi:10.1055/s-2002-20589

[5] Blass, D.M. and Chuen, M. (2004) Olanzapine-associated hypothermia. Psychosomatics, 45, 135-139. doi:10.1176/appi.psy.45.2.135

[6] Hägg, S., Mjörndal, T. and Lindqvist, L. (2001) Repeated episodes of hypothermia in a subject treated with haloperidol, levomepromazine, olanzapine, and thioridazine. Journal of Clinical Psychopharmacology, 21, 113-115. doi:10.1097/00004714-200102000-00023

[7] Kreuzer, P., Landgrebe, M., Hajak, G., Burger, S.J. and Langguth, B. (2011) A case of severe hypothermia following single-dose administration of olanzapine: A case report. Journal of Clinical Psychopharmacology, 22 February 2011.

[8] Kreuzer, P., Landgrebe, M., Wittmann, M., Hajak, G., Schencklmann, M., Poeppl, T.B. and Langguth, B. (2011) Hypothermia under olanzepine treatment: Clinical case series and review of current literature. Der Nervenarzt, 83, 630-637. doi:10.1007/s00115-011-3310-y

[9] Rasnayake, L.R., Wimalarathne, H., Jayapala, R.K., Gamage, C.D., Dassanayake, D.L., Ratnayake, S.L., Colombage, A., Nandadeva, D. and Nelumdeniya, A.N. (2011) An usual case of hypothermia associated with therapeutic doses of olanzapine: A case report. Journal of Medical Case Reports, 18, 189.

[10] Norris, M.L., Spettigue, W., Buchhol, A., Henderson, K.A., Gomez, R., Maras, D., Gaboury, I. and Ni, A. (2011) Olanzapine use for the adjunctive treatment of adolescents with anorexia nervosa. Journal of Child and Adolescent Psychopharmacology, 21, 213-220. doi:10.1089/cap.2010.0131

[11] Hein, I.M. and Huyser, C. (2010) Olanzepine in de behandeling van adolescenten met anorexia nervosa. Tijdschrift voor Psychiatrie, 52, 417-421.

[12] Phan, T.G., Yu, R.Y. and Hersch, M. (1998) Hypothermia induced by risperdone and olanzapine in a patient with Prader-Willi syndrome. Medical Journal of Australia, 169, 230-231.

[13] Parris, C., Mack, J.M., Cochiolo, J.A., Steinmann, A.F. and Tietjen, J. (2001) Hypothermia in 2 patients treated with atypical antipsychotic medication. Journal of Clinical Psychopharmacology, 62, 61-63. 


\section{doi:10.4088/JCP.v62n0112g}

[14] Fukunishi, I., Sato, Y., Kino, K., Shirai, T. and Kitaoka, T. (2003) Hypothermia in a hemodialysis patient treated with olanzepine monotherapy. Journal of Clinical Psychopharmacology, 23, 314. doi:10.1097/00004714-200306000-00013

[15] Lee, T.W., Tsai, S.J. and Hwang, J.P. (2003) Severe cardiovascular side effects of olanzapine in an eldery patient: Case report. The International Journal of Psychiatry in Medicine, 33, 399-401. doi:10.2190/U99G-XDML-0GRG-BYE0

[16] Hung, C.F., Huang, T.Y. and Lin, P.Y. (2009) Hypothermia and rhabdomyolysis following olanzapine injec- tion in an adolescent with schizophreniform disorder. General Hospital Psychiatry, 31, 376-378. doi:10.1016/j.genhosppsych.2008.09.009

[17] Muñoz, M.T. and Argente, J. (2002) Anorexia nervosa in female adolescents: Endocrine and bone mineral density disturbances. European Journal of Endocrinology, 147, 275-286. doi:10.1530/eje.0.1470275

[18] Oerther, S. and Ahlenius, S. (2000) Atypical antipsychotics and dopamine $\mathrm{D}(1)$ receptor agonism: An in vivo experimental study using core temperature measurements in the rat. Journal of Pharmacology and Experimental Therapeutics, 29, 731-736. 